UDC: $634.25-152.782(497.11)$

COBISS.SR-ID: 211607052

Original research paper

Acta Agriculturae Serbica, Vol. XIX, 37 (2014); 27-39

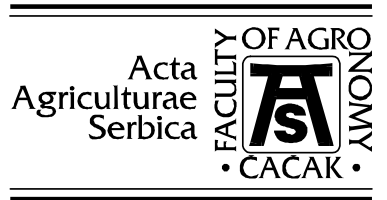

\title{
Evaluation of the course of microsporogenesis in some selected peach (Prunus persica L./Batsch) cultivars
}

\author{
Jana Horsáková, Boris Krška \\ Department of Fruit Growing, Faculty of Horticulture Lednice, Mendel \\ University in Brno, Czech Republic
}

\begin{abstract}
The evaluation of the microsporogenesis process was performed from January to April within the period of 2011-2013. The experiment involved 15 peach cultivars and the control cultivar Redhaven. The course of microsporogenesis was evaluated on the base of microscopic observations.

It was found out that cultivars under study differed not only in the total length of microsporogenesis but also in dates of the onset of individual developmental stages. The shortest period of the development of pollen grains was detected in the cultivar W 13 (viz. 89 days) while the longest ones were found out in cultivars W 43 and Super Queen (in both of them the average duration of microsporogenesis was 106 days. In the control cultivar Redhaven the average length of the period of microsporogenesis was 104 days. In individual cultivars, the course of microsporogenesis was different and was dependent on meteorological conditions existing in individual years.
\end{abstract}

Key words: Peach tree, microsporogenesis, pollen, flower buds. 


\section{Introduction}

Pollen is one of the elementary factors that influence the fertility of fruit woody species. In general, the size of pollen grains ranges from 10 to $200 \mu \mathrm{m}$ and in peach trees (Prunus persica (L.) Batsch) its size ranges from 26 to $50 \mu \mathrm{m}$ (Halbritter, 2000). Pollen develops from mother cells called archesporia that are situated in microsporangia (pollen sacs). After a meiotic reduction, haploid tetrads are produced and these develop into pollen grains during the process called microsporogenesis (Blackmore et al. 2007). Thus, that the term microsporogenesis means the development of pollen grains. The process of microsporogenesis was studied by Sholokhov (1972) and thereafter a number of other authors. Qiangsheng et al. (1992) studies directly the species $P$. persica. Basing on results of his studies on a set of Chinese peach tree cultivars, they distinguished 3 levels and 9 stages of the development of pollen grains. In Hungary, the course of the process of microsporogenesis in peaches was studied by Szalay et al. (2002). There are many other studies that present a detailed anatomical and morphological description of mature pollen grains (Zhu et al. 1998, Luo et al. 1999, Sótonyi et al. 2000, Radice et al. 2003). The microsporogenesis is closely associated also with the frost resistance of floral buds. The existence of a correlation between microsporogenesis and the degree of tolerance of flower buds to frosts was corroborated also by Szabo et al. (2002).

When studying flower buds and monitoring the process of microsporogenesis, it is also possible to use the method of measuring of pistil length; this was described in detail by Szalay (2006). Samples used in studies on the course of microsporogenesis should be taken from morphologically parallel parts of tree crowns and from annual shoots of the same type because Neméth and Szalay (2012) mentioned that they observed differences in the development of pollen grains on short $(0-20 \mathrm{~cm})$ and long $(40-80 \mathrm{~cm})$ annual shoots.

The aim of this study was to monitor the course of the microsporogenesis and to describe in detail individual stages of the development of pollen grains in some selected peach (Prunus persica (L.) Batsch cultivars.

\section{Materials and methods}

\section{Plant material}

As experimental plant material altogether 15 cultivars from the gene fund of peach trees cultivated in the collection of the MENDELU Faculty of Horticulture 
in Lednice were used (Tab. 1) and compared with the cultivar Redhaven (control).

Table 1. A survey of cultivars

\begin{tabular}{cccc}
\hline Benedicte & Neve & Ruby Prince & Venus \\
(France) & (Italy) & (USA) & (Italy) \\
Fantasia & Redhaven & Spring Belle & W 13 \\
(Italy) & (USA) & (Italy) & (China) \\
Fidelia & Royal Glory & Super Queen & W 14 \\
(Italy) & (USA) & (Italy) & (China) \\
Krymchanin & Rubinovyj 7 & Symphony & W 43 \\
(Ukraine) & (Ukraine) & (France) & (China) \\
\hline
\end{tabular}

The gene fund (collection) of P. persica L. was established in 2001. The spacing of trees with slender spindle crown was $5 \times 1.5 \mathrm{~m}$. As far as the agrotechnical interventions were concerned, trees were treated with preparations suppressing (and/or killing) diseases and pests (Taphrina deformans Champion; Sphaerotheca pannosa - Kumulus; Monilinia laxa - Horizon; aphids - Pirimor). The locality Lednice is situated in the maize-growing region with the altitude of $176 \mathrm{~m}$ a. s. 1 . According to Quitt's classification it belongs to the T4 climatic region with very warm, dry and long summers, warm springs and autumns, short, mild and dry to very dry winters and with a very short duration of snow cover. Within the period of 1961-1990, the basic climatic parameters were as follows: average annual temperature $9.2^{\circ} \mathrm{C}$, average humidity $76.1 \%$, average annual sum of precipitations $479.7 \mathrm{~mm}$ and average annual sum of solar radiation 1,747.3 hours. Within the period of experimental years 2011-2012, the corresponding parameters were $10.5^{\circ} \mathrm{C}, 71.5 \%, 398.4 \mathrm{~mm}$ and $1,978.6$ hours, respectively. A survey of maximum and minimum temperatures recorded in individual study years is presented in Fig. 1. All climatic data were recorded in the meteorological station of Mendeleum (MENDELU Faculty of Horticulture) in Lednice. 


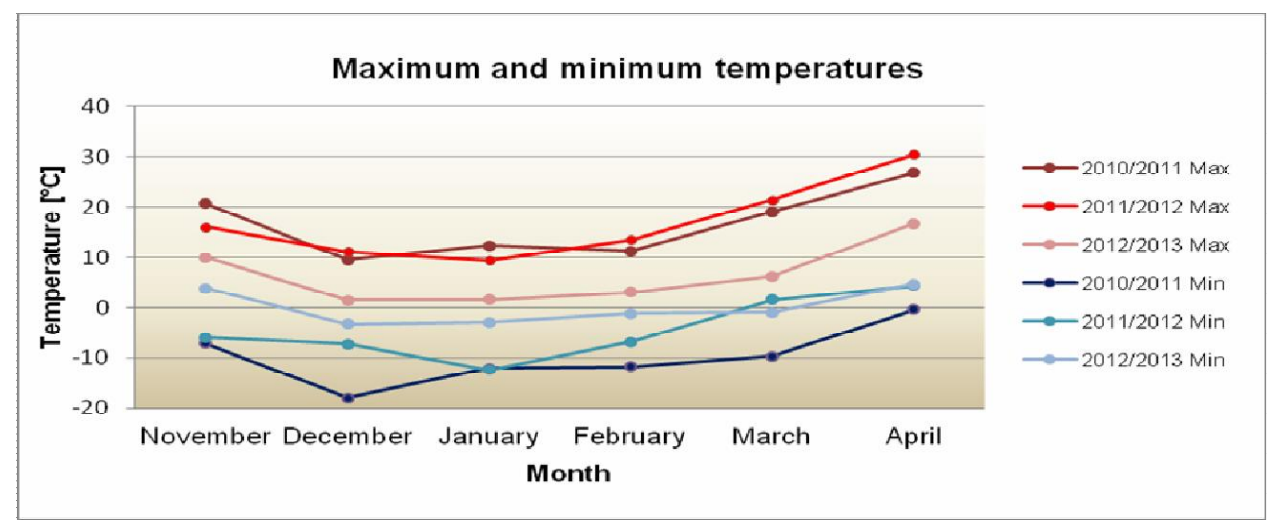

Figure 1. Maximum and minimum temperatures

\section{Evaluation of the course of microsporogenesis}

In all experimental years, samplings of flower buds started at the beginning of January (i.e. on 5 January 2011, 2012 and 2013, respectively) and were performed till the beginning of April. Bud samples were taken in morphologically parallel parts of tree crowns, always on the same cardinal point and in the height of approximately $1.5 \mathrm{~m}$. In the period of meiosis, samplings were performed once a week but, depending on the weather situation and needs of the study, two samplings had to be also performed. For the microscopic evaluation, always 3 flower buds of each cultivar were sampled and the final result was calculated as an average value of these three samples.

Collected samples were used for making of preparations that were studied in detail under the microscope (Olympus, magnification 10 to $100 \times$ ). Each bud was cut radially and the anthers were removed. These anthers were thereafter placed to a microscopic slide and covered with 1-2 drops of a suitable agent (glycerine, Lugol's solution, acetocarmine). Glycerine was used within the first two stages; later on, either Lugol's solution or acetocarmine were used to highlight individual details of the preparation under study. The final preparation was covered with a micro cover glass and the anthers were crushed by a slight pressure on the cover glass. The following stages of microsporogenesis were studied under the microscope (Sholokhov, 1972):

- Development of the archesporial tissue

- Maternal sac of the anther

- Reduction division

- Formation of microspore tetrads

- Pollen grain with one nucleus

- Pollen grain with two nuclei

- Starch synthesis in pollen grains 
The duration of development of pollen grains was expressed as the sum of days elapsing since the $1^{\text {st }}$ January of a given year (Stage 1) till the stage of starch synthesis in pollen grains (Stage 7).

\section{Statistical processing of results}

Obtained results were processed statistically (multifactorial analysis if variance, Fisher's test) using the software StatSoft (STATISTICA 10).

\section{Results and Discussion}

The duration of the development of pollen grains of cultivars under study is presented in Tab. 2. It is always expressed as the sum of days elapsing since the $1^{\text {st }}$ January of a given year.

Table 2. Duration of the development of pollen grains

\begin{tabular}{lcccc}
\hline Cultivar & \multicolumn{4}{c}{$\begin{array}{c}\text { Duration of the development of pollen grains since the } \\
\text { beginning of January (in days) }\end{array}$} \\
\hline W 13 & $\mathbf{2 0 1 1}$ & $\mathbf{2 0 1 2}$ & $\mathbf{2 0 1 3}$ & Mean \\
Symphony & 70 & 89 & 107 & 89 \\
Venus & 102 & 75 & 113 & 97 \\
Ruby Prince & 95 & 89 & 106 & 97 \\
Benedicte & 95 & 87 & 113 & 98 \\
Spring Belle & 95 & 87 & 114 & 99 \\
Royal Glory & 102 & 88 & 106 & 99 \\
Fantasia & 95 & 89 & 113 & 99 \\
Fidelia & 95 & 96 & 113 & 101 \\
Krymchanin & 102 & 89 & 113 & 101 \\
Neve & 95 & 96 & 116 & 102 \\
Redhaven & 101 & 93 & 113 & 102 \\
Rubinovyj 7 & 102 & 96 & 113 & 104 \\
W 14 & 102 & 96 & 113 & 104 \\
Super Queen & 99 & 89 & 126 & 105 \\
W 43 & 102 & 96 & 120 & 106 \\
\hline
\end{tabular}


Lengths of individual stages of microsporogenesis are presented in Fig. 2. Also in this case their duration is expressed as the sum of days elapsing since the $1^{\text {st }}$ January of 2011 . As one can see, in the majority of cultivars under study, the total length of the development of pollen grains was about 100 days. The shortest period of the development of pollen grains was recorded in the cultivar W 13 (70 days). Monitored cultivars differed not only in the duration but also in dates of the onset of individual stages of microsporogenesis.

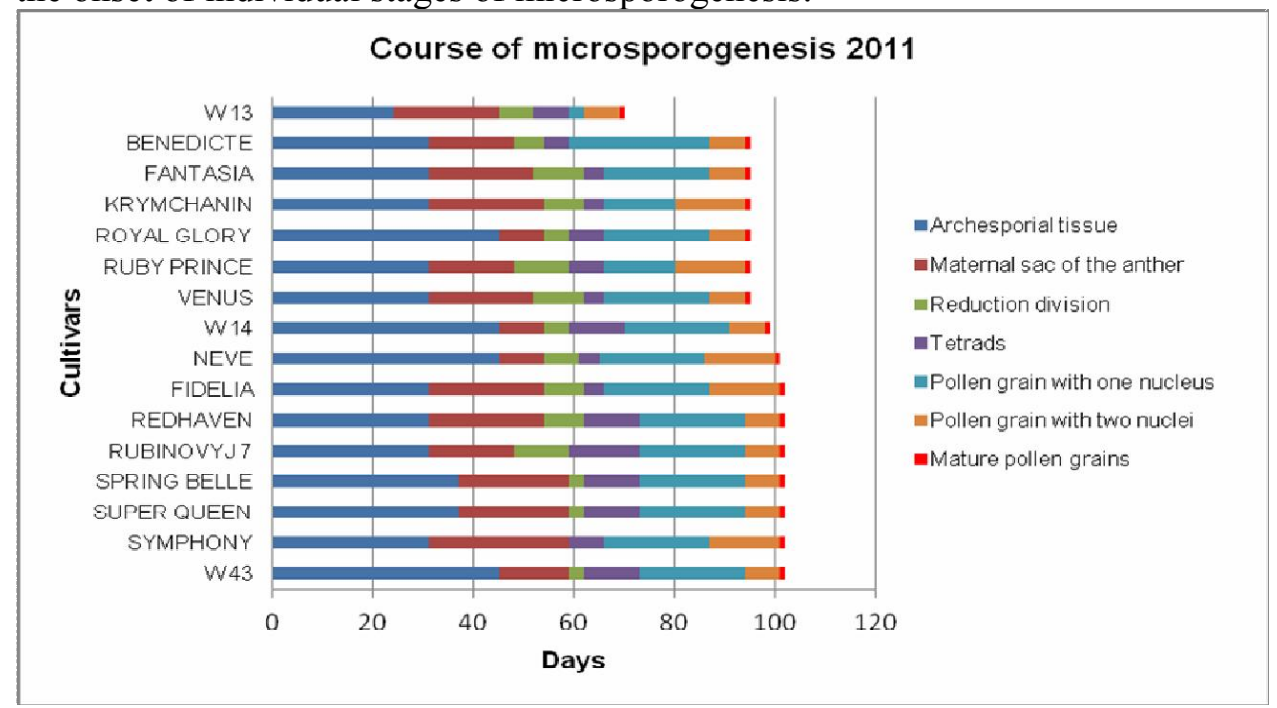

Figure 2. Course of microsporogenesis in 2011

The development of the archesporial tissue ranged between 24 and 45 days (in average 35 days). The shortest stage of the development of the archesporial tissue was recorded in the cultivar W 13. The second stage (i.e. the stage of the development of the maternal sac of anthers) lasted 9 to 28 days (in average 19 days). The course of meiosis that was visible in stage 3 was very short and ranged from 3 to 11 days (in average 7 days). Depending on the cultivar, the duration of stage 4 (development of tetrads) was also very short and ranged from 4 to 11 days (in average 8 days). Formation of pollen grains with one nucleus took place after the breakup of tetrads; this stage was the longest and lasted in average 20 days. The cultivar $\mathrm{W} \mathrm{13}$, in which this stage lasted only 3 days, was the only exception. The second nucleus was visible in pollen grains in average after 9 days; within this stage, the pollen grains markedly increased in size and the starch synthesis began. This was indicated by the black colour of grains. Also in this stage the cultivar W 13 produced as the first mature pollen grains (on 29 March 2011). Thereafter, mature pollen grains were observed in cultivars Benedicte, Venus, Royal Glory, Ruby Prince and Krymchanin (on 5 April 2011). 
In all other cultivars under study, mature pollen grains were observed one week later, i.e. on 12 April 2011.

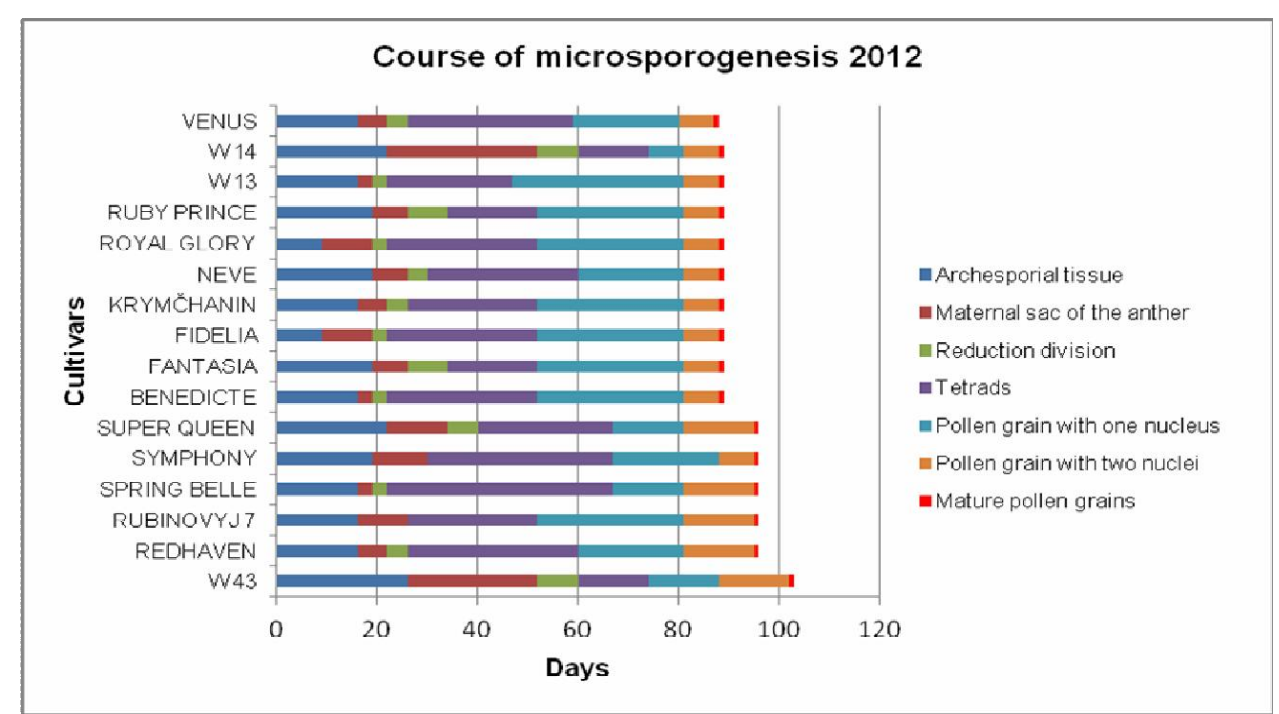

Figure 3. Course of microsporogenesis in 2012

In 2012, the period of the development of pollen grains was shorter and only cultivar W 43 it lasted from more than 100 days. In this year, the development of archesporial tissue was markedly shorter and ranged from 9 to 26 days (in average 17 days). In the majority of cultivars under study, the second developmental stage was relatively short and lasted from 3 to 10 days; exceptions were observed only in cultivars W 14 and W 43 (with 30 and 26 days, respectively). The stage of visible meiosis (i.e. the stage 3 ) was also very short and lasted only 3-8 days (in average 4 days). In two cultivars, no symptoms of meiosis were recorded on the date of observation. The stage of tetrad formation was the next one; as compared with the year 2011, it was relatively longer and lasted in average 26 days. The stage of uninuclear pollen grains lasted in average 23 days and was longer by 4 days than in 2011. In pollen grains, the second nucleus could be observed in average after 9 days. The length of this stage was the same as in 2011. The first mature pollen grains were observed on 29 March 2012 in the majority of cultivars under study. On 5 April 2012, mature pollen grains were observed in cultivars Symphony, Spring Belle, Super Queen, Rubinovyj 7 and Redhaven. The cultivar W 43 was the latest and its first mature pollen grains were observed as late as on 12 April 2012.

In 2013, he period of the microsporogenesis was longer than 100 days. The longest period of the development of pollen grains was recorded in the cultivar 
W 14 (126 days).The period of the development of archesporial tissue was comparable with the year 2011 and lasted 16 to 38 days (in average 27 days).

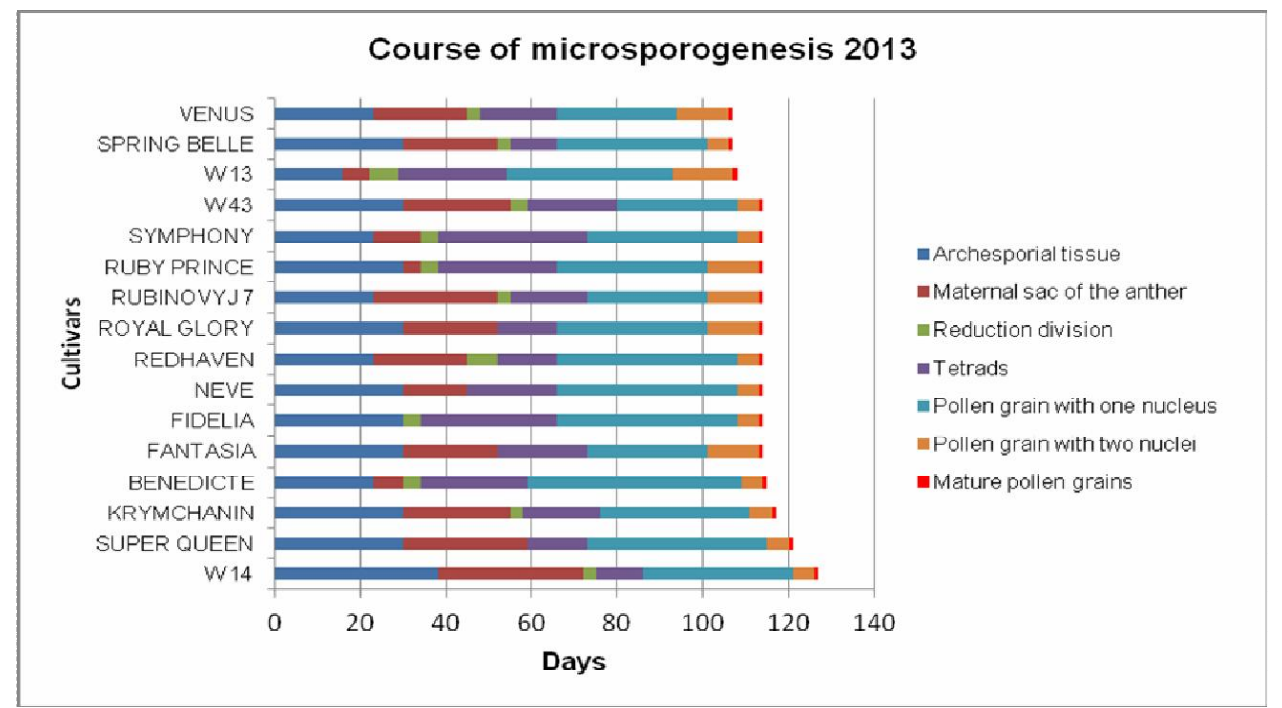

Figure 4. Course of microsporogenesis in 2013

The second developmental stage lasted 4 to 34 days (in average 18 days). The course of meiosis was again very rapid and ranged between 3 and 7 days (in average 3 days). In altogether four cultivars no meiosis was recorded on the date of observation. The stage of tetrad formation lasted 11 to 35 days (in average 20 days). The stage of uninuclear pollen grains was longer than in 2011 and 2012 and lasted in average 36 days. In pollen grains, the second nucleus could be observed in average after 7 days. The first mature pollen grains were observed in the cultivar W 13 on 19 April 2013; in other cultivars under study, the first mature pollen grains were observed on 24 April 2013, i.e. much later than in 2011 and 2012.

The period of formation of archresporial tissue is the longest stage of microsporogenesis. It begins already in November and lasts (depending on the cultivar and climatic factors) till the half or even to the end of January. In this developmental stage, cells are densely packed and they are of an irregular shape (Fig. 5a). In the next stage (called maternal sac of anthers), these cells are already slightly rounded and are a little larger than in first stage (Fig. 5b). The meiotic stage runs very quickly: cells divide, they are of spherical shape and their coat (testa) is clearly demarcated and visible (Fig. 5c). Tetrads result from the reduction cell division (Fig. 5d); this means that there are always four microspores inside the cell and they represent the basic element of a pollen grain. Uninuclear pollen grains as well as external and internal coats called 
intine and exine are the result of the breakup of tetrads (Fig. 5e). This breakup is followed by the stage of binuclear pollen grains; pollen grains are greater and the larger two of them (vegetative) should be visible while the visibility of remaining two (generative ones) should be relatively complicated and more difficult. However, black centres of cell are mostly visible. The intensity of this black colour gradually increases till the moment when the pollen grains become completely black and the last stage of the microsporogenesis, i.e. the stage of starch synthesis (Fig. 5f) begins and takes place.

a) Archesporial tissue b) Maternal sac of anthers

c) Meiosis

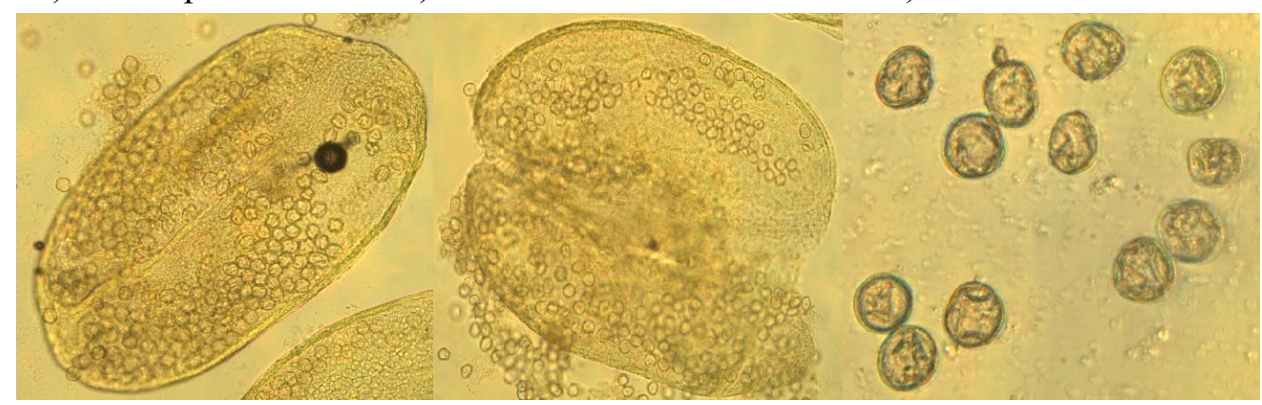

d) Tetrads

e) Breakup of tetrads

f) Starch synthesis

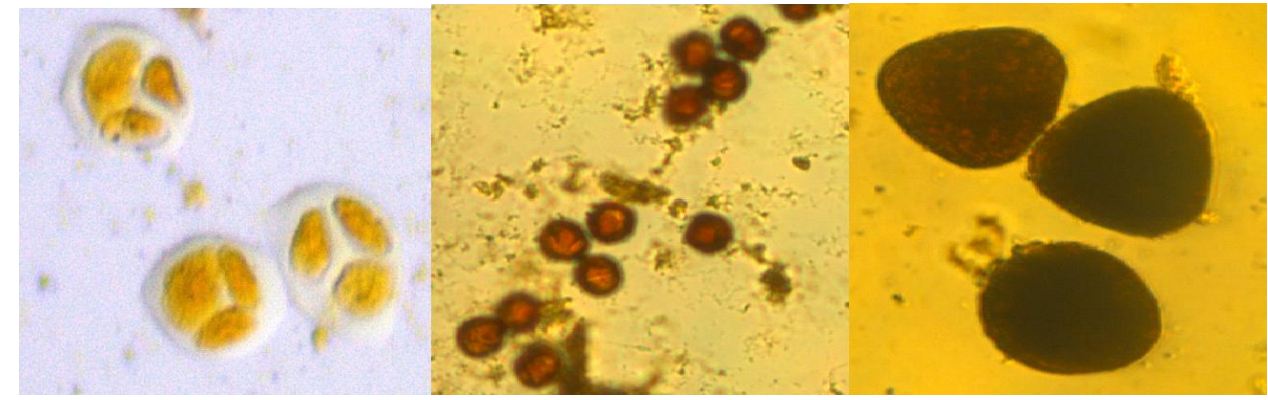

Figure 5. Stages of the microsporogenesis

It is well known that glycerin $\left(\mathrm{C}_{3} \mathrm{H}_{8} \mathrm{O}_{3}\right)$ is the best reagent that can be used when observing the archesporial tissue under the microscope. In later stages of the pollen grains development (when it is necessary to highlight individual details of preparations under study) it is also recommended to use Lugol's solution (i.e. aqueous $\mathrm{KI}_{3}$ solution). It is also possible to use acetocarmine $\left(\mathrm{C}_{22} \mathrm{H}_{20} \mathrm{O}_{13}\right.$ in $\left.\mathrm{C}_{2} \mathrm{H}_{4} \mathrm{O}_{2}\right)$, which gives similar results as Lugol's solution and can be thus used for staining of preparations under study.

The statistical analysis revealed highly significant differences in the length of periods of pollen grains development between cultivars W 13 - Super Queen $(\mathrm{p}=0.0008), \mathrm{W} 13-\mathrm{W} 43(\mathrm{p}=0.0008), \mathrm{W} 13-\mathrm{W} 14(\mathrm{p}=0.0017), \mathrm{W} 13-$ 
Redhaven $(p=0.0031)$ and W $13-$ Rubinovyj $7(p=0.031)$. In these cultivars both the shortest and the longest intervals of the development of pollen grains were detected between the cultivar $\mathrm{W} 13$ on the one hand and other cultivars under study on the other). Further it was also found out that there were significant differences between the cultivar W 13 on the one hand and other cultivars on the other (Fidelia $p=0.0107$, Spring Belle $p=0.0107$, Neve $p=$ 0.0128 , Krymchanin $p=0.0211$, Benedicte $p=0.0292$, Fantasia $p=0.0342$, Royal Glory $p=0.0342$, Ruby Prince $p=0.0342$ and Venus $p=0.0400$ ). As far as other cultivars under study were concerned, the differences in the duration of the period of pollen grain development were insignificant. It was also found out that in years 2011, 2012 and 2013 the differences in the length of the period of pollen grain development were statistically highly significant, viz. $p=0.0000 ; p$ $=0.0000$ and $p=0.0036$ ). This indicated that in individual years under study the development of pollen grains showed to be considerably different.

In the course of microsporogenesis there were also shifts in individual phenophases of flower buds.

Every year, the process of microsporogenesis was markedly influenced by existing weather conditions (this was quite clear just in years 2011-2013. In 2011, the course of all climatic factors showed to be normal; the only exception was observed in December when the temperatures were unusually high and nontypical; the average temperature was $0.7^{\circ} \mathrm{C}$ and there were only two days when the diurnal temperatures were below zero. January of 2012 was also very warm and the average temperature was $1.3{ }^{\circ} \mathrm{C}$. This means that just this factor caused a shortening of the stage of the development of the archesporial tissue. In 2012, the following stage was shorter, the length of meiosis similar, the stage of tetrads much longer, the stage 5 nearly comparable, the length of the stage 6 was identical and mature pollen grains occurred two weeks earlier than in 2011. Year 2013 was similar to the year 2011; the only difference were observed between lengths of the stage of tetrads and the stage of uninuclear pollen grains; in 2013 this stage was longer and also mature pollen grains were observed much later than in both preceding years.

Basing on results of a microscopic study on the course of microsporogenesis it can be concluded that peach (P. persica (L.) Batsch) cultivars differ not only in the duration but also in the date of onset of individual phenophases of the development of flower buds. The existence of differences in the course of microsporogenesis among peach cultivars and years under study were reported also by Radice (2005), Szalay (2006) and Neméth and Szalay (2012). As far as other fruit tree species were concerned, similar results of studies on the microsporogenesis similar results obtained for example Hajnal et al. (2013) in their study on apricots. Popovska et al. (2005) studied the course of microsporogenesis in sour cherries published and published similar results. 


\section{Conclusion}

The length of the period of the development of pollen grains is different not only in individual cultivars but also in individual years. In cultivars under study, the duration of this period ranged from 89-106 days. The shortest period of the development of pollen grains pollen grain (in average 89 days) was recorded in the cultivar W 13 while the longest one was observed in cultivars W 43 and Super Queen (in average 106 days). In the control cultivar Redhaven, the average duration of microsporogenesis was 104 days. The course of microsporogenesis and the duration of individual stages of the development of pollen grains were significantly influenced by different meteorological conditions existing in individual years of study. It seems that for practical growing the most suitable are cultivars with slower course of microsporogenesis; on the other hand, however, they must show also good pomological properties. A slower course of the microsporogenesis combined with a later break of the dormancy could be used in the domain of breeding and selection. Of cultivars under study, it is possible to recommend W 43 and/or Super Queen.

\section{References}

Blackmore S., Wortley A. H., Skvarla J. J., Rowley J. R., 2007. Pollen wall development in flowering plants. New Phytologist, 174(3): 483-498.

Hajnal V., Zarif O., Ladányi M., Tóth M., Szalay L., 2013. Microsporogenesis of Apricot Cultivars in Hungary. Notulae Botanicae Horti Agrobotanici Cluj-Napoca, 41(2): 434-439.

Halbritter H., Prunus persica. In: Buchner R. \& Weber M. (2000 onwards). PalDat a palynological database: Descriptions, illustrations, identification, and information retrieval.

Published on the Internet http://www.paldat.org/index.php?module $=$ search\&nav $=$ sd $\& I D=11813 \&$ system $=1 \& p$ ermalink=116509 [accessed 2014-03-26].

Leida C. A., 2012. Molecular aspects of dormancy in peach (Prunus persica [L.] Batsch). [Ph.D. Thesis.] Universitat Politècnica de València: 1-153.

Luo L. S., Xiao D. X., Huo G. H., Liu Y., Gu Q. Q., 1999. A primary study on male sterility in peach. I. Phenotypes and abortive ways of the first batch of 23 male sterile breeds of peach. Acta Agric. Univ. Jiangxiensis, 21(4): 463-468.

Németh S. Z., Szalay L., 2012. Quantitative parameters of peach and apricot flower bud development. Acta Hort. (ISHS), 962:253-259.

Popovska M., Angelova E., Popovski B., 2005. Microsporogenesis of sour cherries in the Skopje region. Acta Hort. (ISHS), 667:111-116.

Qiangsheng W., Yinping S., Jinzheng W., Congyi S., 1992. Development of pollen grain in peach. Acta Hort. (ISHS), 315: 229-236. 
Radice S., 2005. Biología floral y reproductiva del cultivar Forastero (Prunus persica [L] Batsch.) Rosaseae, Prunoideae, en estiones crecidos sobre pies francos o clonales macro y micropropagados. - [Ph.D. Thesis.] Buenos Aires University.

Radice S., Galati B. G., 2003. Floral Nectary Ultrastructure of Prunus persica L. Batch cv. Forastero (Newcomer), an Argentine Peach. Plant Syst. Evol. 238: 2332

Sótonyi P., Szabó Z., Nyéki J., Benedek P., Soltész M., 2000. Pollen morphology of fruit species. Int. J. Hort. Sci., 6(3): 49-57.

Szabó Z., Szalay L., Papp J., 2002. Connection between the developmental stage and the cold hardiness of peach cultivars. Acta Hort. (ISHS), 592:549-552.

Szalay L., 2006. Comparison of flower bud development in almond, apricot and peach genotypes. Int. J. Hort. Sci. 12(2): 93-98.

Szalay L., Timon B., Szabó Z., Papp J., 2002. Microsporogenesis of peach (Prunus persica L. Batsch) varieties. Int. J. Hort. Sci., 8(3/4): 7-10.

Sholokhov A. M., 1972. Studium morfogeneze květních pupenů v souvislosti s odrůdovými pokusy a šlechtěním na mrazuodolnost (Metodické pokyny). Yalta.

Zhu G.R., Gong F.C., Zuo Q.Y., Wang L.R., 1998. Peach pollen measuring and analysis J. Fruit Sci, 15 (4): 360-363. 


\title{
PROCENA TOKA MIKROSPOROGENEZE NEKIH SORTI BRESKVE
}

\author{
Jana Horsáková, Boris Krška \\ Katedra za voćarstvo, Fakultet za Hortikulturu Lednice, \\ Mendelov Univerzitet u Brnu, Čě̌ka Republika
}

\section{Rezime}

Procena toka mikrosporogeneze izvršena je od januara do aprila u periodu od 2011 - 2013. godine. Eksperiment se sastojao od 15 sorti breskve i kontrolne sorte Redhaven. Tok mikrosporogeneze je utvrđen na osnovu mikroskopskih posmatranja.

Utvrđeno je da su se ispitivane sorte razlikovale, ne samo u dužini trajanja ukupnog procesa mikrosporogeneze, već i u datumu početka pojedinih razvojnih faza. Najkraći period razvoja polenovih zrna utvrđen je kod sorte W 13 (89 dana), dok su najduži periodi bili kod sorti W 43 i Super Queen (kod obe je prosečna dužina mikrosporogeneze bila 106 dana). Kod kontrolne sorte Redhavena period mikrosporogeneze je trajao 104 dana. Pojedine sorte su imale drugačiji tok mikrosporogeneze u zavisnosti od meteoroloških uslova koji se javljaju u pojedinim godinama.

Ključne reči: Breskva, mikrosporogeneza, polen, cvetni pupoljci. 